\title{
Internal Audit Techniques and Fraud Prevention: A Case Study of Selected Local Government Councils in Bauch State
}

\section{Onoja Emmanuel E, Ph.D}

\author{
Department of Accounting, Kogi State University,Anyigba \\ Email:onojaandco@ymail.com \\ Haruna Usman \\ Department of Accounting, Kogi State University, Anyigba
}

\section{Doi:10.5901/mjss.2015.v6n4p232}

\section{Abstract}

This study analyzes the Internal Audit Techniques and Fraud Prevention in Bauchi State Local Government Councils. The relevant literatures were reviewed. The data for the study were collected from both the primary and secondary sources. The primary sources data were collected from the thirteen (13) local governments internal audit units through self-administered questionnaires to the sample size of the study. The secondary sources were documents from Bauchi state ministry for local government affairs. Several statistical tools were used including tables, simple percentages, Chi-square and Pearson Product Moment Correlation Coefficient to analyze the data and test the null hypotheses formulated. The study revealed that the internal audit unit at local government put necessary measures to prevent fraud but lack total independent freedom to carry out their function effectively. The paper concludes that The internal audit units at local government level in Bauchi state are performing the function of fraud prevention and the internal audit techniques/procedures capable to prevent any type of fraud was effective. It was discovered that internal audit unit at local governments' level in Bauchi state are not independent, and this affected their functions. The study recommends among other things that, Bauchi state government through House of Assembly should enact laws/legislation that will grant internal audit unit autonomy to discharge their functions. Effective internal audit techniques/procedures capable of preventing fraud should be installed by the councils and that adequate measures and control should be put in place.

Keywords: internal, audit, Local government Council, Techniques, Prevention, Fraud

\section{Introduction}

Internal audit being a unit in any establishment set up by the management of an organization for the review of internal control system as a service to the organization. The objective is to assist members of the organization including those in management and the board in the effective discharge of their responsibilities. To this end, internal auditing furnishes management of local governments with analysis, appraisals, recommendations, counsel and information concerning the activities reviewed

Chartered Institutes of Public Finance and Accountancy UK 2003 define Internal audit as an assurance function that primarily provides an independent and objective opinion to the organization on the degree to which the internal control environment supports and promotes the achievement of the organizations objectives. It objectively examines, evaluates and reports on the adequacy of internal control as a contribution to the proper, economic, efficient and effective use of resources, internal audit a component of government financial management and a tool for improving the performance of the government sector (Diamond, 2002: 1).

Recently, there has been increased interest and more emphasis placed on the internal audit function. Reason being that, internal audit unit at local government serves as control point that checks the activities and affairs of financial dealings of any organization. This has arisen from a number of sources. In Organization for Economic Corporation and Development (OECD) countries, the demand for improved accountability and greater transparency within government has resulted in a call for more information about government programs and services,(Diamond 2002:5).

Internal audit in local government and other public and private sectors serves as a control mechanism (Cohen, \& Sayag 2010) in Badara and Saidin (2013). There seems to be impediments infringing on local government's functions and performance in recent times. These impediments range from political undue interference from the higher levels of 
government, that is, State and Federal government.

The local government, as the closest tier of government to the people in Nigeria was established as a means for providing socio-economic development at the grass root level. To this, resources have always been allocated but no commensurable achievement seen. This is what members of the general public alleged as fraud, corruption and failure of the internal audit unit to install control mechanism that would minimize misuse of resources in the local government (Kwanbo \& Dabo, 2009).

Internal audit is a statutory function required within every local government organization as established by the local government Act of 1972. The local government system model financial Memoranda (1988), describe the internal auditor as an officer of the local government charged with the responsibility for conducting internal audit of the management for the finances of the local government. Internal auditor is also charged with the responsibility of safeguarding the assets and liabilities of an organization and other constructive services that will enhance the efficiency and effectiveness of the operations of the organization, through review, accounting systems, review of internal control systems, review of the implementation of the corporate policies, plans and procedures and possibly through carrying out special investigations assigned by the organization.

\subsection{Statement of the Problem}

Local government funds are to be applied in developmental and social projects for the welfare of their citizens. Over the years citizen are not satisfied with the manner in which the resources of local government councils are channeled, $(G a r k o, 2010)$. Some of the problems range from inadequate allocations, limited sources of revenue, inefficiencies, weak internal control system and audit technique resulting to leakages and fraud. Since the establishment of Local government Council, series of reforms have taken place with the aims of ensuring its objectives of effective and efficient utilization of resources. Internal audit unit being an integral part of the finance structure of the local government needs to be structured with all the necessary resources and support for its effective function.

A constant complaint in the sector by the general public especially the residents of the local areas who are closer to local authority is that, the unit which is established to check the financial dealings of the local government (internal audit unit) is too weak in its functions either as a result of inadequate staffing, weak internal control, poor administration, lack of required personnel, inadequate documentation, and application of appropriate internal audit techniques in the local governments, among others, to prevent fraud (Unegba \& Kida, 2011; and Garko, 2011). Therefore, the study intents to look at internal audit technique and fraud prevention in Buachi State local governments.

The general objective of this study is to examine the internal audit technique and fraud prevention in Bauchi State local government.

The specific objectives are the following:

i. To determine the relevance of internal audit technique in fraud prevention in Bauchi state local governments.

ii. To determine the relationship between internal audit techniques and traditional internal auditing approach in fraud prevention in the local governments.

iii. To determine the measures put in place to by the management to prevent fraud in Bauchi state local government.

In order to address the problems identified in the study and to achieve the objectives, the following questions were raised:

I. Does internal audit techniques to prevent fraud in Bauchi state local government?

II. Is there any difference between internal audit technique (interview \& analytical) and traditional internal check in fraud prevention in the local government?

III. Does the management of Bauchi sate local government Council put all the necessary measures in place to prevent frauds?

In line with the statement of the research questions and the objectives of the study, the following hypotheses were formulated to guide the study:

Ho1. Traditional internal audit approach does not prevent fraud in Bauchi state local government.

Ho2. Interview and analytical technique does not prevent fraud in Bauchi state local government.

$\mathrm{Ho}_{3}$. There is no significant relationship between internal audit technique and traditional internal auditing approach in fraud prevention at the local government. 


\subsection{Significance of the Study}

Findings from the study will adequately reveal the strengths and weaknesses of internal audit unit in carrying out their functions. This study is important to Local government councils by knowing the effectiveness of internal audit technique and its role in controlling and safeguarding the resources of the local government in Bauchi state against fraud and irregularities. It will assist to assess the contributions that internal audit can provide in alleviating fraud and its prevention. This study is also important to Bauchi state ministry for local government and chieftaincy affairs, by providing basis for evaluating and assessing control installed by the audit units in the financial dealings at the local government councils. It would therefore be of immense value as it will contribute to the existing literature and motivate researchers who may be interested to carry out similar study on the internal audit unit of local government in Nigeria.

\section{Literature Review and Theoretical Framework}

\subsection{Concept of Internal Audit}

The Internal audit function has received increasing attention as an important component of government financial management and a tool for improving the performance of the government sector, (Diamond, 2002 and IFA, 2001), Governing bodies of public sector entities need to ensure that an effective internal audit function is established as part of the framework of control. Auditing functions of local government has a vital role in ensuring that effectiveness and efficiency is maintained in the local councils.

Jurchescu, (2010) defined internal audit" as an independent and objective functional activity which provides security and management advice with the aim of ensuring effective management of public income and expenditure, ensuring proper activities within public organization, helps the public organization to achieve their objective through systematic and methodical approaches, evaluate and improves the efficiency and effectiveness of internal control system, risk management and management processes".

Unegbu and kida (2011) defined internal audit as "an aspect of the internal control system established by management of an organization in order to ensure proper compliance with the stipulated policies and procedure in order to achieve management objectives". This definition indicates that the internal auditor is part of internal control system established within the organization with the aim of evaluating the efficiency and effectiveness of other controls established by management. From all the above definitions, internal audit can be seen as independent appraisal established within the organization with the aim of reviewing the effectiveness and efficiency of the activities of an organization, ensuring compliance with established regulations, evaluation of risk management and internal controls system of the organization.

Adeniji (2004) sees internal audit as a review of organization of a business which may be in many respects similar to a statutory audit, but which is carried out by the employees of the business who are responsible only to management. The scope and objectives of internal audit vary widely, depending on the nature and areas of application. He observed that internal audit operates on one or more of the following broad areas:

Review of compliance: this review may cover compliance with guidelines, laws, regulations and other external requirements and with internal policies and directives and, other requirements including appropriate authorization of transactions.

Special investigation: this is carrying out on special circumstances; the scope and report only cover the circumstances investigated. It includes investigation for suspected fraud, credit purpose, back duty, investment, and business combination

\subsection{System Audit}

A system audit is based on a testing and evaluating of internal controls within a system to determine what reliance can be placed on those controls to ensure that resources are being managed effectively and information provided accurately. In other words, a system audit is an audit of internal controls in a system. This kind of audit characterized most of the work of internal audit departments and a system audit involves caring out two types of tests:

Compliance test: test seeking evidence that the internal controls are applied as prescribed

Substantive test: once compliance tests are conducted, further tests are required to substantiate the entries in the figures in accounts.

Adeniji (2004) opined that when internal audit department investigates a system, effort should be made in 
identifying the control objectives of the system, and evaluating the systems of internal controls on paper. They should determine whether the internal controls that currently exist appear to be adequate, so that:

Controls exist which meet the overall objectives of the system.

There are controls to prevent or identify errors and omissions that occur during operations.

These procedures are necessary steps to achieve internal audit objectives. After the preliminary investigation of the system's controls, an audit should carry out compliance test to obtain reasonable assurance that the controls on which he wishes to rely were functioning both properly and throughout the period. Compliance test are followed by substantive tests. These are tests of individual transactions and balances, and other procedures such as analytical review, which seek to provide audit evidence as to the completeness, accuracy and validity of the information contained in the accounting records or financial statements. Compliance and substantive tests occupy such an important place in the day to day work of an internal audit department.

The importance of the two types tests are that if the compliance test reveal that internal controls are working satisfactorily, then the amount of substantive testing can be reduced, and the internal auditor can concentrate his/her audit effort on those areas where controls do not exist or are not working satisfactorily.

The contemporary audit ecology

Peecher, Schewartz \& Solomon (2007), cited that there are many ways in which one can characterize an environment as complex as the audit environment. We choose to emphasize four dimensions of the audit environment of today:

(1) Audited entities are employing new business models, 4 business strategies, and processes; there are reduced barriers to competition; the pace of change is accelerating.

(2) There is heightened concern about and responsibility for detecting management fraud resulting in misstated financial statements.

(3) There is consistent evidence that, although infrequent, when audit failures occur, they are typically due to inadequate control of non-sampling risk/error.

(4) The Audit Risk Model (ARM) persists as a prominent aid for planning the audit and organizing audit quality control efforts on individual engagements.

\section{Internal Audit Techniques}

\subsection{Analytics Technique}

Analytics is not a technology; it's a concept. It refers to the use of certain technologies, skill sets, and processes for the exploration, evaluation, and investigation of business operations. It can be used to drive planning, gain insight, and optimize the internal audit lifecycle. The practice of analytics makes extensive use of data, statistical and quantitative analysis, explanatory and predictive modeling, and fact-based management to drive decision making. There are several disciplines contained within the scope of an analytics initiative: analytics methodology, analysis tools, performance management, descriptive statistics, exploratory data analysis, confirmatory data analysis, as well as data management. Used together, the disciplines of analytics provide hindsight, insight, and foresight. There are several factors that have really fueled the rise in the use of analytics in Internal Audit functions. Analytics - which is already used in many areas of the business, such as finance, workforce management, supply chain management, and customer relationship management - can help meet these expectations. Applying analytics to the internal audit process can facilitate moving beyond the traditional internal audit activities toward an environment of more sophisticated risk analysis and monitoring. By leveraging the power of analytics, the internal audit process can produce insights and conclusions that help decision makers take action quickly and make more effective, timely decisions, (Zarkaryi,2006 \& Delloitte 2012).

Analytics provides answers to decision makers from three perspectives: historical, current, and future - i.e., it provides hindsight, insight, and foresight. It can help users ask such questions as, "What happened, and why?", "Where is the problem, and what actions do I need to take to solve it?", "What will happen if these trends continue?", and finally, and perhaps most importantly, "What's the best/worst that could happen?" This predictive capability of analytics supports the shift toward dynamic risk-focused audit planning and audit execution over static traditional planning approaches.

Perhaps one of the biggest challenges that the internal audit process faces today is the expectations of the C-suite and Audit Committee, that Internal Audit should support the business by delivering deeper insight and greater value more efficiently and effectively. Some of the more challenging expectations of Internal Audit include:

- Being more efficient and achieving more with less

- More effectively identifying and responding to risk 
- Delivering more robust and effective analysis of key issues

- Providing more meaningful actionable insights

- Driving change within the business

By applying analytic tools and techniques, internal auditors obtain deeper insight into their data, systems, and processes and gain the ability to ask - and answer - new and more complex questions about government transactions. They can move from asking "What do we need to do?" to "What do we need to know?" The shift is subtle, but powerful.

\subsection{Application of Analytic Technique in Fraud Detection}

Where analytics can be applied is in fraud detection and exception identification algorithms; these are often based upon anomaly detection schemes. Myriad techniques can be employed from logical risk scoring to decision trees to stochastic link analysis. Applying these techniques in combination detects transactions that are the most likely to exhibit fraudulent or exceptional characteristics. Further automating and scheduling these routines helps Internal Audit to move toward automated detection and exception-based auditing.

\subsection{Reasons for the use of Analytic Audit technique}

There are several factors that have really fueled the rise in the use of analytics in Internal Audit functions. The first is the explosion of data volumes both structured and unstructured. With this explosion have come innovations in the capture of, and reporting on, that data. The next is the increasing expectations of key stakeholders' vis-à-vis the nature and value of reported information that the internal audit process produces. As the revenue accruing to local government in recent years grows increasingly, stakeholders require deeper insights and clearly stated facts to support decisions, build greater value, and create a more dynamic focus on accountability.

\subsection{Theoretical Framework}

According to the agency theory, a company consists of a nexus of contracts between the owner of economic resources" (the principals) and manager (the agents) who are charged with using and controlling those resources" (Jensen and meckling, 1976). Agency theory posits that. Agents have more information then principal, and that such information asymmetry adversely affects the principals' ability to monitor whether or not their interests are being properly served by agents. Furthermore, an assumption of agency theory is that, principal and agents act rationally and use contracting to maximize their own wealth. A consequence of this assumption may be the "moral" hazard" problem (Jensen and meckling, 1976) where to maximize their own wealth; agents may face the dilemma of acting the interests of their principles. Since principals do not have access to all available information at the time a decision is being made by an agent, they are unable to determine whether (called adverse selection) and the moral hazard problem, principle and agents engage in contracting to achieve pareto-optimality, including the establishment of monitoring processes such as internal auditing (Adams, 1994). Specifically internal auditing is considered a bonding cost borne by agents to satisfy the principals for accountability (sherer \& 1983).

Stewardship theory, according to this theory; manager is expected to be good stewards of organizational resources. They are not to misappropriate organizational resources as this, will adversely affects the attainment of other non-financial motives, such as the intrinsic satisfaction of successful performance and the need for achievement and recognition. to agency costs (DeFond, 1992; Anderson \& stokes, 1993; Ettredge, Reed \& Stone, 2000).

However, very few studies have used the agency theory to explain the importance of internal auditing in organizations (Francis \& Wilson, 1988; wallace \& Kreutzfeldt, 1991; DeFound, 1992; and Adams, 1994) for the purposes of this study, both" agency theory and stewardship theory" were used to relate local government administrators, internal audit unit and government. To relate the above theories to this study, the local administrators act as an agent on behalf of the government (general public) and this resulted into failure of local government in the area of services delivery.

For the application of stewardship theory to this study, it is expected that that, local government official are entrusted with the management of public resources at local government level which will give account of how these resources are being managed, under their care to the general public. Thus, proper audit by independent and competent internal audit unit are required to check into affair of these resources entrusted on them in order to ensure efficiency and accountability in local government 


\section{Methodology}

For the purpose of this study, thirteen (13) local governments was selected representing $65 \%$ using simple random sampling technique to enable generalization to be made on the population. The local governments selected, has total number of 91 internal audit staff comprising both senior and junior staff, (see appendix iv) and they constitute the respondents of this study, out of which Seventy eight (78) questionnaires were duly filled and retrieved from the respondents. This number presents $86 \%$ of the questionnaires returned

Data were gathered from both primary and secondary sources. The primary data for this study came from questionnaire. While secondary data were collected from the Bauchi State Ministry for Local Government and Chieftaincy Affairs, Bulletin with specific focus on internal audit and fraud prevention.

In order to analyze the data generated for the study, the researcher used three different types of statistical techniques. These are descriptive statistics, chi-square test and Pearson Product Moment Correlation Coefficient.

\subsection{Decision Rule}

The null hypothesis is rejected if the calculated value of $r$ - ratio is greater than the critical value of $r$ as given in the $r$ distribution table otherwise, it stands accepted in the case of Pearson Product Moment Correlation Coefficient.

The null hypothesis is rejected if the calculated value of $X^{2}$ is greater than the critical value of $X^{2}$ as given in the $X^{2}$ distribution table otherwise; it stands accepted in the case of Chi-square.

\section{Data Presentation and Analysis}

The data generated from the questionnaires administered were analyzed and interpreted using descriptive statistics, while all hypotheses were tested using Chi-square technique and Pearson Product Moment Correlation Coefficient method.

\subsection{Answering of Research Questions}

Research Question 1: Are internal audit techniques (interview \& analytic) relevant to prevent fraud in Bauchi state local government?

Table 1: Mean rating of respondents on the relevant of internal audit technique in preventing frauds

\begin{tabular}{|c|l|c|c|c|}
\hline S/N & ITEM STATEMENT & N & MEAN & REMARK \\
\hline 1 & $\begin{array}{l}\text { Internal Audit Unit (IAU) has been applying interview and analytic audit technique to prevent over-valuation } \\
\text { of contracts and supplies }\end{array}$ & 78 & 3.62 & Agree \\
\hline 2 & IAU has been applying interview and analytic audit technique to prevent Improper related party transaction & 78 & 3.26 & Agree \\
\hline 3 & IAU has been applying interview and analytic audit technique to prevent Fictitious contracts and supplies & 78 & 3.81 & Agree \\
\hline $\begin{array}{l}\text { IAU has been applying interview and analytic audit technique to prevent Diversion of funds/assets and } \\
\text { unauthorized payment to third parties }\end{array}$ & 78 & 3.10 & Agree \\
\hline & IAU has been applying interview and analytic audit technique to prevent Misappropriation of funds/assets. & 78 & 4.01 & Agree \\
\hline & IAU has been applying interview and analytic audit technique to prevent Falsification of financial records & 78 & 2.86 & Disagree \\
\hline $\begin{array}{l}\text { IAU has been applying interview and analytic audit technique to prevent Submission of claims for } \\
\text { services/goods not supplied }\end{array}$ & 78 & 3.85 & Agree \\
\hline
\end{tabular}

Source: Field survey ( 2015)

Table 1 depicts mean and standard deviation values of the respondents to questions relating to the relevance of internal audit technique in frauds prevention in Bauchi state local governments. The value of the options available to respondents ranges from 5-1. From the table, the average respondents agreed that analytic and interview technique of auditing is relevance in frauds prevention at the local government. On the instances of over-valuation contract and supplies, the mean is 3.62. It also found that internal audit unit has been applying interview and analytic audit technique to prevent improper related party transaction with mean of 3.26. This indicate that audit unit at the local government are aware and have been applying progressive technique (analytic and interview) in auditing procedures in it function of preventing frauds but failed due to lack of absolute independent from their employers (management). On the application of the 
technique in preventing fictitious contracts and supply, diversion of funds and misappropriation of funds, has corresponding mean and standard deviation of $3.81,3.10$ and 4.01 respectively. This shows that the responses affirm to the to the issue of relevance of internal audit technique in fraud prevention with exception of the technique preventing falsification of financial records with mean 2.26 and standard deviation around 0.136 which disagree that the technique cannot prevent instances of the fraud.

Research Question 2: Is there any difference between internal audit technique (interview \& analytic) and traditional internal auditing in fraud prevention in the local government?

Table 2: Mean and standard deviation of respondents on the fraud prevention techniques

\begin{tabular}{|c|c|c|c|}
\hline Fraud Prevention Techniques & N & Mean & SD \\
\hline Interview \& analytic & 78 & 3.50 & 1.27 \\
\hline Traditional & 78 & 1.85 & 1.09 \\
\hline
\end{tabular}

Source: Field survey, 2014

Table 1 above depicts the mean and standard deviation of respondents on adoption of two different internal audit techniques in fraud prevention in Bauchi state local governments. Interview \& analytic technique has mean of 3.50 and SD of 1.27 while traditional procedure has mean of 1.85 and SD of 1.09. It is indicated that Interview \& analytic technique has high mean value. The difference in the mean $=1.65$ which shows the difference in the two techniques.

Research Question 3: Do the management of Bauchi sate local government areas put all the necessary measures in place to prevent frauds?

Table 3: Mean rating of respondents on management efforts in frauds prevention

\begin{tabular}{|c|c|c|c|c|}
\hline S/N & ITEM STATEMENT & $\mathrm{N}$ & MEAN & REMARK \\
\hline 1 & $\begin{array}{c}\text { The management of the local government put all necessary measures in place, } \\
\text { to prevent frauds }\end{array}$ & 78 & 2.89 & Disagree \\
\hline
\end{tabular}

Source: Field survey, 2014

The table above shows the analysis of the responses on the management efforts in fraud prevention at Bauchi state local government with mean of 2.89 less than the sample mean of 3, which disagree with the assertion. This indicates that management being part of the organization and employer of the internal audit staff, assumed control of the system rendering the audit unit independent to which they can carry out their statutory functions.

\subsection{Testing of hypotheses}

\subsubsection{Hypothesis one}

Ho1. Traditional internal audit approach cannot prevent fraud in Bauchi state local government.

\section{Table 4}

\begin{tabular}{ccccccccccc}
\hline Staff Category & S A & A & U & SD & D & Total & Df & $\chi^{2}$ critical & $X^{2}$-cal. & Decision \\
\hline Senior staff & 34 & 18 & 1 & 2 & 0 & 55 & & & \\
Junior staff & 4 & 8 & 4 & 4 & 3 & 23 & 4 & & 0.001 & Accept Ho \\
\hline
\end{tabular}

Source: Field survey, 2014

Table 4 above depicts the $x^{2}$ calculated and critical value on the null hypothesis Traditional internal audit approach cannot prevent fraud in Bauchi state local government at 4 degree of freedom. The $\chi^{2}$ calculated is 0.001 less than $\chi^{2}$ critical 9.49 which made the researcher to accept the null hypothesis thereby rejecting the alternative hypothesis which state that 
Traditional internal audit approach can prevent fraud in Bauchi state local government.

\subsubsection{Hypothesis Two}

Ho2. Interview and analytic technique cannot prevent fraud in Bauchi state local government.

Table 5: Chi-Square on use of interview and analytic techniques in fraud prevention

\begin{tabular}{ccccccccccc}
\hline Staff Category & SA & A & U & SD & D & Total & Df & $\mathbf{X}^{2}$ critical & $\chi^{2}$-cal. & Decision \\
\hline Senior staff & 5 & 2 & 9 & 19 & 20 & 55 & & & & \\
Junior staff & 4 & 6 & 8 & 2 & 3 & 23 & & & & \\
\hline
\end{tabular}

Source: Field survey, 2014, generated by the Author using SPSS 16.0

The above table 5 presents the result of chi-square tests on the use of interview and analytic techniques at the Bauchi state local government. The $x^{2}$-calculated is 11.23 which is greater than the $x^{2-c r i t i c a l ~ o f ~} 9.49$, thus rejecting the null hypothesis that state Interview and analytic technique cannot prevent fraud in Bauchi state local government. Therefore, Interview and analytic technique can prevent fraud in bauchi state local government.

\subsubsection{Hypothesis Three}

Ho3. There is no significant relationship between internal audit technique and traditional internal auditing approach in fraud prevention at the local government.

Table 6:

\begin{tabular}{cccccccc}
\hline Audit Techniques & $\mathrm{N}$ & $\mathrm{X}$ & $\mathrm{SD}$ & $\mathrm{Df}$ & r-critical & r-cal. & Decision \\
\hline Senior staff & 78 & 1.85 & 1.10 & & & & \\
Junior staff & 78 & 3.53 & 1.33 & & 0.28 & 0.72 & Reject $\mathrm{Ho}_{2}$ \\
\hline
\end{tabular}

Source: Field survey, 2014

Table 6 above depicts the result of Pearson Product Moment Correlation Coefficient test on the significant relationship between internal audit technique and traditional internal auditing approach in fraud prevention at the local government. The r-calculated is 0.72 which is significant compare to $r$-critical found to be 0.28 . it therefore reject the null hypothesis that state there is no significant relationship between internal audit technique and traditional internal auditing approach in fraud prevention at the local government. Thus, accepting the alternative hypothesis that state, there is significant relationship between internal audit technique and traditional internal auditing approach in fraud prevention at the local government.

\section{Summary, Conclusion and Recommendations}

\subsection{Summary}

Local government Council in Bauchi state apply internal audit techniques in fraud prevention and detection, but found to be weak and ineffective in discharging this function, due to undue interference from management.

Management of Bauchi state local governments do not make serious effort in providing the necessary measures in ensuring that fraud and irregularities are reduce to bearable minimal, as such the internal audit techniques/procedures responsible for preventing fraud at the local governments are ineffective. 


\subsection{Conclusions}

The internal audit is an integral unit in any organization and local governments in Bauchi state are not exception. This is because, internal audit enhance the internal control system at the local government level, though the internal auditors of the local governments are answerable to their respective chief executives, ensures the implementation of internal audit technique.

This study has revealed that, the internal auditors at the local governments level are under undue influence of the chief executive whom the auditors are suppose to report to. This menace of lack of independence from the management has eroded control in the local government financial systems in Nigeria and hence poor performances by the local government that is closer to the people at the grass-root.

\subsection{Recommendations}

Based on the above conclusions, the study recommends the following:

Bauchi state government should enact laws that will grant internal audit unit autonomy to discharge their functions.

Effective internal audit technique capable of preventing any type of fraud should be established by internal audit unit and that adequate measures and control should be put in place as to prevent fraud through sound control environment that will ensure that policies and plans are implemented.

To ensure that the independent of internal audit units are not compromised, a Board of Enquiry should always be commissioned at the state level to review the effectiveness of the internal audit and other control systems of the local governments at regular intervals. State government through the local government service commission should organize on-going seminars and workshops to re-educate internal audit unit on relevant internal audit techniques and standards related to fraud and how to applying them in preventing fraud at the local government level.

\section{References}

\section{Books}

Adeniji, A. A. (2004), Auditing and investigation, Lagos, value analysis consult publishes.

Aguolu, O. (2009). Designing an Effective Internal Audit Group. Association of Accountancy Bodies in West Africa, 1(4), 60-76.

Aquisua, F. D.(1994), Principles Of Auding And Investigation,1 st edition, NAF HQFC, Kaduna.

Ayeni, A. (1992); civil Service for Structural Adjustment, Lagos: Nigerian Institute of Management (NIM)

CIPFA (2003) Code of Practice For Internal Audit In Local Government In The United Kingdom

CIPFA (2006) Code of Practice For Internal Audit In Local Government In The United Kingdom

Connel, N. O. (2006); Local Government Audit Service Activity Report

Dandago, K. I. (1999), Auditing In Nigeria: A Comprehensive Text, Kano, Adamu joji publishers Ltd.

Diamond, J. (2002), The Role of Internal Audit in Government Financial Management: An International Perspective, IMF working Paper, Fiscal affairs Department

Fayemi, O. A. (1991); Principle of Local Government Accounting, Lagos Yaba Chapter Ten Publication Ltd

Federal Republic of Nigeria-FRN (1988); Model Financial Memoranda for Local Governments: Federal Government Press.

Federal Republic of Nigeria-FRN (1991); Model Financial Memoranda for Local Governments: Abuja Government .

Garko, J. S. (2010), The Role of Internal Audit Unit in Fraud Prevention and Detection at Local Government Level in Kano State: A Study of Some Selected Local Governments

IFA (2001), Governance in the Public Sector: A Governing Body Perspectives, New York.

Ikpe, D. N., OKpomechile, J. I. and Okeke, E. N. (2007); Modernizing the Role of Internal Auditor in the Local Government System in Nigeria.

Institute of Internal Auditors IIA (1978); Standards for the Professional Practice on Internal Auditing, the Internal Auditor: United Kingdom.

Jensen, M. C. and Meekling, W. H. (1976); 'theory of the firm: Management Behaviour, Agency costs, ownership structure'. Journal of Financial Economics, 3(4): 355-665.

Jivegard, J. andSjolin, J, (2005); Local Government Audit, a study of the expected from the New Legislations; Healthy Finances

Kurfi, A. K. (2005); Business Law in Nigeria; Kano Benchmark Publishers Limited

Mamman, S. (2006) the Application of Due Process at the Local Government: Challenges and Constraints in Dandago, K. I. and Hamid, K. T. (eds.), Commitment and Due Process proceedings of the $4^{\text {th }}$ National Conference on ethical issues in Accounting, organized by the department of Accounting Bayero University, Kano. Vol.4, pp.2-17.

Maryam, m. (2007) an assessment of internal revenue Generation Efforts of local Government in Yobe State, being M.sc thesis submitted to accounting department, Bayero Universities, Kano. (Unpublished). 
Millichamp, A. H. (2002), Auditing, $8^{\text {th }}$ edition, ELST publisher

Mohammad, M. L.(2004): The impact of internal Audit on Accountability in Nigeria organizations, in Dandago, K. I. and Tanko, A. I. (eds.), Prudence, Accountability and Transparency in accounting, proceedings of the $2^{\text {nd }}$ National Conference on ethical issues in Accounting, organized by the department of Accounting Bayero University, Kano. Vol.2, Pp.170-186.

Morenikeji, W. (1999); Essentials of Research methods For Social Sciences, planners and environmentalist, Gabaster Educational Printers, Ibadan

Okolo, J. U. T. (1987); The Concept and Practice of Auditing, Ibadan Evans Brother Ltd.

Oladoyin, M. A. (2004), Accountability And Transparency In Revenue Generation in Dandago, K. I. and Tanko, A. I. (eds.), Prudence, Accountability and Transparency in accounting, proceedings of the $2^{\text {nd }}$ National Conference on ethical issues in Accounting, organized by the department of Accounting Bayero University, Kano. Vol.2, pp. 67-84.

Osaze, B. E. \& Izedonmi, P. F. (2008), Guidelines for Writing Thesis and Dissertations for Postgraduate Students in Africa; Streams communications, Lagos

Owojori,A. A. (2002), Managerial Research, Kaycee publishers Ado-ekiti.

Sherer, M. and Kent, D. (1983); Auditing and Accounting, London Pitman

Tanko, M. (2003): Internal Control And Fraud Prevention In The Nigerian Banking Industry, in : Dandago, K. I. and Tanko, A. I. (eds.), Background issues to ethics in accounting, proceedings of the $1^{\text {st }}$ National conference on ethical issues in accounting, organized by the department of Accounting Bayero University, Kano. Pp.185-194.

Tanko, M. (2004), An Assessment of Internal Audit function in Local Government Councils: A case of Kaduna State in Dandago, K. I. and Tanko, A. I. (eds.), Prudence, Accountability and Transparency in accounting, proceedings of the $2^{\text {nd }}$ National Conference on ethical issues in Accounting, organized by the department of Accounting Bayero University, Kano. Vol. 2, pp 367-385.

Wynne, A. (2001), Audit Independence: The Case Of The Nigerian Public Service

Ye, M. and Zhang P. (2011), The Impact of Auditing Standards Convergence on Audit Value; University of Toronto, Canada retrieved on 31st March, 2013 from: http://ssrn.com/abstract=1769051

\section{Journals}

Adams, M. B. (1994); Agency Theory and the Internal Audit'. Managerial Auditing journal, 9(8), 8-12

Al-Twaijry, A. A. M, Brierley, J. A, \& Gwilliam, D. R. (2003). The development of internal audit in Saudi Arabia: An Institutional Theory perspective. Critical Perspective on Accounting, 14, 507-531. doi:10.1016/S1045-2354(02)00158-2.

Al-Twaijry, A. A.M., Brierley, J. A, \& Gwilliam, D. R.(2004). An examination of the relationship between internal and external audit in the Saudi Arabian corporate sector. Managerial Auditing Journal, 19(7), 929 -944.

Badara, M. S. and Saidin, S. Z. (201); Antecedents of Internal Audit Effectiveness: A Moderating Effect of Effective Audit Committee at Local Government Level in Nigeria, International Journal of Finance and Accounting 2(2): 82-88

Defond, M. L. (1992); The Association Between Changes in Client Firm Agency Costs and Auditor Switching'. Auditing : A Journal of Practice and Theory, 11(1); 16-31

Eden, D., \& Moriah, L.,(1996) "Impact of internal auditing on branch bank performance: a field experiment".Organizational Behavior and Human Decision Processes, 68(3),

Ettredge, M. Reed, M. and Stone M. (2000); 'An Examination of Substitution Among Monitoring Devices: The Case of Internal and External Audit Expenditures; Review of Quantitative Finance and Accounting 15(1); 57-79

Fowzia, R. (2010). Co-operation between internal and external auditors: A comparative study on Nationalized and Foreign Banks in Bangladesh. World Journal of Management, 2(2), 22 - 35.

Francis, J. R. and Wilson, E. R (1988); Auditor Changes a Joint Test of Theories Relating to agency Costs and Auditor Differentiation; the Accounting Review 13(4) 663-682

Holder, W. W. (1980), A Study of Selected Concepts for Government Financial Accounting and Reporting, Chicago: National Council on Government Accounting.

Johns, D. C. (1984), Municipal Accounting for Developing Countries, London: Chartered Institute of Public Finance and Accountability; and World Bank, Washington DC.

Kwanbo, M. L. and Dabo, Z. (2009), Internal control system and the issues of independence and confidentiality in local Governments auditing: An examination. A conference paper, presented at the $5^{\text {th }}$ annual conference organized by Accounting Department of Bayero University, Kano, from $14^{\text {th }}-17^{\text {th }}$ April.

Mihret, D. G, \& Admassu, M. A. (2011). Reliance of external auditors on internal audit work: A corporate governance perspective. International Business Research, 4(2), 67-79.

Mizrahi S. and Ness-Weisman I. (2007),Evaluating the Effectiveness of Auditing in Local Municipalities using Analytic Hierarchy Process (AHP): A General Model and the Israeli Example; International Journal of Auditing.

Mizrahi, S. \& Ness-Weisman, I. (2007), Evaluating the Effectiveness of Auditing in Local Municipalities Using Analytic Hierarchy Process (AHP): A General Model and the Isreal Example

Munroa, L, \& Stewart, J. (2011). External auditors' reliance on internal auditing: Further evidence. Managerial Auditing Journal, 26(6), $464-481$.

Roy, J. P. (1989), Financial Reporting by Canadian Municipalities: A Survey of Annual Financing Report of 60 Canadian Municipalities for 1987. Toronto, Canada: Canadian Institute of Chartered Accountants. 
Internet

Akenbor E. O. \& Ironkwe U.,( 2014) :Forensic Auditing Techniques and Fraudulent Practices of Public Institutions in Nigeria; Journal of Modern Accounting and Auditing, Vol. 10, No. 4, 451-459; rerieved 8th January, 2015 from: http://www.davidpublishing.com/david publishing/Upfile/5/6/2014/2014050607143898.pdf

\section{Appendix I}

\begin{tabular}{|c|c|c|c|c|c|c|c|c|c|c|c|c|c|c|c|}
\hline \multicolumn{16}{|c|}{ Field Survey Responses } \\
\hline$\stackrel{\vec{E}}{\stackrel{\vec{I}}{\underline{I}}}$ & 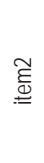 & 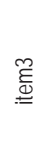 & $\stackrel{\stackrel{\nabla}{E}}{\underline{\Xi}}$ & $\stackrel{\llcorner 0}{\stackrel{\llcorner}{\Xi}}$ & $\begin{array}{l}\mathscr{E} \\
\stackrel{\Xi}{ \pm}\end{array}$ & 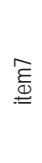 & $\stackrel{\infty}{\stackrel{\infty}{\mathscr{I}}}$ & 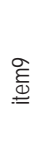 & 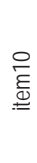 & 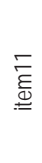 & 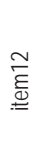 & $\underset{\stackrel{m}{E}}{\stackrel{m}{ \pm}}$ & 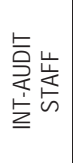 & $\frac{0}{\frac{U}{5}}$ & 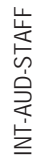 \\
\hline 5 & 5 & 5 & 5 & 5 & 5 & 5 & 5 & 5 & 5 & 5 & 5 & 5 & 2 & 5 & 2 \\
\hline 5 & 5 & 5 & 5 & 5 & 5 & 5 & 5 & 5 & 5 & 5 & 5 & 5 & 2 & 5 & 2 \\
\hline 5 & 5 & 5 & 5 & 5 & 5 & 5 & 5 & 5 & 5 & 5 & 5 & 5 & 2 & 5 & 2 \\
\hline 5 & 5 & 5 & 5 & 5 & 5 & 5 & 5 & 5 & 5 & 5 & 5 & 4 & 2 & 5 & 1 \\
\hline 5 & 5 & 5 & 5 & 5 & 5 & 5 & 5 & 5 & 5 & 5 & 5 & 4 & 2 & 5 & 1 \\
\hline 5 & 5 & 5 & 5 & 5 & 5 & 5 & 5 & 5 & 5 & 5 & 5 & 4 & 2 & 5 & 1 \\
\hline 5 & 5 & 5 & 5 & 5 & 5 & 5 & 5 & 5 & 5 & 5 & 5 & 4 & 2 & 5 & 1 \\
\hline 5 & 5 & 5 & 5 & 5 & 5 & 5 & 5 & 5 & 5 & 5 & 5 & 4 & 1 & 5 & 1 \\
\hline 4 & 5 & 5 & 5 & 5 & 5 & 5 & 5 & 5 & 5 & 5 & 5 & 4 & 1 & 5 & 1 \\
\hline 4 & 5 & 5 & 5 & 5 & 5 & 5 & 5 & 5 & 5 & 5 & 5 & 3 & 1 & 5 & 1 \\
\hline 4 & 5 & 5 & 5 & 5 & 5 & 5 & 5 & 5 & 5 & 5 & 5 & 3 & 2 & 5 & 1 \\
\hline 4 & 5 & 5 & 5 & 5 & 5 & 5 & 5 & 5 & 5 & 5 & 5 & 3 & 2 & 5 & 1 \\
\hline 4 & 5 & 4 & 5 & 5 & 5 & 5 & 5 & 5 & 5 & 5 & 5 & 3 & 2 & 5 & 1 \\
\hline 4 & 5 & 4 & 5 & 5 & 5 & 5 & 5 & 4 & 5 & 5 & 5 & 3 & 2 & 5 & 1 \\
\hline 4 & 5 & 4 & 5 & 5 & 5 & 5 & 5 & 4 & 5 & 5 & 5 & 2 & 2 & 5 & 1 \\
\hline 4 & 5 & 4 & 5 & 5 & 5 & 5 & 5 & 4 & 5 & 5 & 5 & 2 & 2 & 5 & 1 \\
\hline 4 & 5 & 4 & 5 & 5 & 5 & 5 & 5 & 4 & 5 & 5 & 5 & 2 & 2 & 5 & 1 \\
\hline 4 & 5 & 4 & 5 & 4 & 5 & 5 & 5 & 4 & 5 & 4 & 5 & 2 & 2 & 5 & 1 \\
\hline 4 & 5 & 4 & 5 & 4 & 5 & 4 & 5 & 4 & 5 & 4 & 5 & 2 & 2 & 5 & 1 \\
\hline 4 & 5 & 4 & 5 & 4 & 5 & 4 & 5 & 4 & 5 & 4 & 5 & 2 & 2 & 5 & 1 \\
\hline 4 & 5 & 4 & 5 & 4 & 5 & 4 & 5 & 4 & 5 & 4 & 5 & 2 & 1 & 5 & 1 \\
\hline 4 & 5 & 4 & 5 & 4 & 5 & 4 & 5 & 4 & 5 & 4 & 5 & 2 & 1 & 5 & 1 \\
\hline 4 & 5 & 4 & 5 & 4 & 5 & 4 & 5 & 4 & 5 & 4 & 5 & 2 & 1 & 5 & 1 \\
\hline 4 & 5 & 4 & 4 & 4 & 4 & 4 & 5 & 4 & 5 & 4 & 4 & 2 & 1 & 4 & 1 \\
\hline 4 & 5 & 4 & 4 & 4 & 4 & 4 & 4 & 4 & 5 & 4 & 4 & 2 & 1 & 4 & 1 \\
\hline 4 & 5 & 4 & 4 & 4 & 4 & 4 & 4 & 4 & 5 & 4 & 4 & 2 & 1 & 4 & 2 \\
\hline 4 & 5 & 4 & 4 & 4 & 4 & 4 & 4 & 4 & 5 & 4 & 4 & 2 & 1 & 4 & 2 \\
\hline 4 & 4 & 4 & 4 & 4 & 4 & 4 & 4 & 4 & 5 & 4 & 4 & 2 & 1 & 4 & 1 \\
\hline 4 & 4 & 4 & 4 & 4 & 4 & 4 & 4 & 4 & 5 & 4 & 4 & 2 & 1 & 4 & 1 \\
\hline 4 & 4 & 4 & 4 & 4 & 4 & 4 & 4 & 4 & 4 & 4 & 4 & 2 & 1 & 4 & 1 \\
\hline 4 & 4 & 4 & 4 & 4 & 4 & 4 & 4 & 4 & 4 & 3 & 4 & 2 & 1 & 4 & 1 \\
\hline 4 & 4 & 4 & 4 & 4 & 4 & 4 & 4 & 4 & 4 & 3 & 4 & 2 & 1 & 4 & 1 \\
\hline 4 & 4 & 3 & 4 & 4 & 4 & 4 & 4 & 4 & 4 & 3 & 4 & 2 & 1 & 4 & 1 \\
\hline 4 & 4 & 3 & 4 & 4 & 4 & 4 & 4 & 4 & 4 & 3 & 4 & 2 & 1 & 4 & 1 \\
\hline 4 & 4 & 3 & 4 & 4 & 4 & 4 & 4 & 4 & 4 & 3 & 4 & 2 & 2 & 4 & 1 \\
\hline 4 & 4 & 3 & 4 & 4 & 4 & 4 & 4 & 4 & 4 & 3 & 4 & 2 & 2 & 4 & 1 \\
\hline 4 & 4 & 3 & 4 & 4 & 4 & 4 & 4 & 4 & 4 & 3 & 4 & 2 & 1 & 4 & 1 \\
\hline 4 & 4 & 3 & 4 & 4 & 4 & 4 & 4 & 4 & 4 & 3 & 4 & 2 & 1 & 4 & 1 \\
\hline 4 & 4 & 3 & 4 & 4 & 4 & 4 & 4 & 4 & 4 & 3 & 4 & 2 & 1 & 4 & 1 \\
\hline 4 & 4 & 3 & 4 & 4 & 4 & 4 & 4 & 4 & 4 & 3 & 4 & 2 & 1 & 4 & 1 \\
\hline 4 & 4 & 3 & 4 & 4 & 4 & 4 & 4 & 3 & 4 & 3 & 4 & 1 & 1 & 4 & 1 \\
\hline 4 & 4 & 3 & 4 & 4 & 4 & 4 & 4 & 3 & 4 & 3 & 4 & 1 & 1 & 4 & 1 \\
\hline 4 & 4 & 3 & 4 & 4 & 4 & 4 & 4 & 3 & 4 & 2 & 4 & 1 & 1 & 4 & 1 \\
\hline 4 & 4 & 3 & 4 & 4 & 4 & 4 & 4 & 3 & 4 & 2 & 4 & 1 & 1 & 4 & 1 \\
\hline 4 & 4 & 3 & 4 & 4 & 4 & 3 & 4 & 3 & 4 & 2 & 4 & 1 & 1 & 3 & 1 \\
\hline 4 & 4 & 3 & 4 & 4 & 4 & 3 & 4 & 3 & 4 & 2 & 4 & 1 & 1 & 3 & 1 \\
\hline 4 & 4 & 2 & 4 & 4 & 4 & 3 & 4 & 3 & 4 & 2 & 4 & 1 & 1 & 3 & 1 \\
\hline 4 & 4 & 2 & 4 & 4 & 4 & 3 & 4 & 3 & 4 & 2 & 4 & 1 & 2 & 3 & 1 \\
\hline 4 & 4 & 2 & 4 & 4 & 4 & 3 & 4 & 3 & 4 & 2 & 4 & 1 & 2 & 3 & 2 \\
\hline 4 & 4 & 2 & 4 & 4 & 4 & 3 & 4 & 3 & 4 & 2 & 4 & 1 & 2 & 3 & 2 \\
\hline 4 & 4 & 2 & 4 & 4 & 4 & 3 & 4 & 3 & 4 & 2 & 4 & 1 & 1 & 3 & 2 \\
\hline 4 & 4 & 2 & 4 & 4 & 4 & 3 & 4 & 2 & 4 & 2 & 4 & 1 & 1 & 3 & 2 \\
\hline 4 & 4 & 2 & 4 & 4 & 4 & 3 & 4 & 2 & 4 & 2 & 4 & 1 & 1 & 3 & 2 \\
\hline 4 & 4 & 2 & 4 & 4 & 4 & 2 & 4 & 2 & 4 & 2 & 4 & 1 & 1 & 3 & 2 \\
\hline 4 & 4 & 2 & 3 & 4 & 3 & 2 & 4 & 2 & 4 & 2 & 4 & 1 & 1 & 3 & 1 \\
\hline 4 & 4 & 2 & 3 & 4 & 3 & 2 & 4 & 2 & 4 & 2 & 4 & 1 & 1 & 3 & 1 \\
\hline 4 & 4 & 2 & 2 & 3 & 3 & 2 & 4 & 2 & 4 & 1 & 4 & 1 & 1 & 3 & 1 \\
\hline 4 & 4 & 1 & 2 & 3 & 2 & 2 & 4 & 2 & 4 & 1 & 4 & 1 & 2 & 3 & 1 \\
\hline 4 & 4 & 1 & 2 & 3 & 2 & 2 & 4 & 2 & 4 & 1 & 4 & 1 & 1 & 3 & 2 \\
\hline 4 & 4 & 1 & 2 & 3 & 2 & 2 & 4 & 2 & 4 & 1 & 4 & 1 & 1 & 3 & 2 \\
\hline
\end{tabular}




\begin{tabular}{|l|l|l|l|l|l|l|l|l|l|l|l|l|l|l|l|}
3 & 3 & 1 & 2 & 3 & 2 & 2 & 4 & 1 & 4 & 1 & 4 & 1 & 1 & 3 & 1 \\
\hline 3 & 3 & 1 & 2 & 3 & 2 & 1 & 3 & 1 & 4 & 1 & 4 & 1 & 1 & 2 & 1 \\
\hline 3 & 3 & 1 & 2 & 3 & 2 & 1 & 3 & 1 & 4 & 1 & 4 & 1 & 1 & 2 & 2 \\
\hline 3 & 2 & 1 & 2 & 2 & 2 & 1 & 2 & 1 & 4 & 1 & 4 & 1 & 1 & 2 & 2 \\
\hline 2 & 2 & 1 & 2 & 2 & 2 & 1 & 2 & 1 & 4 & 1 & 3 & 1 & 1 & 2 & 2 \\
\hline 2 & 2 & 1 & 2 & 2 & 2 & 1 & 2 & 1 & 4 & 1 & 3 & 1 & 1 & 2 & 2 \\
\hline 2 & 2 & 1 & 2 & 2 & 2 & 1 & 2 & 1 & 4 & 1 & 2 & 1 & 1 & 2 & 2 \\
\hline 2 & 2 & 1 & 1 & 2 & 2 & 1 & 2 & 1 & 3 & 1 & 2 & 1 & 1 & 2 & 2 \\
\hline 2 & 2 & 1 & 1 & 2 & 2 & 1 & 2 & 1 & 2 & 1 & 2 & 1 & 1 & 2 & 1 \\
\hline 2 & 1 & 1 & 1 & 2 & 2 & 1 & 2 & 1 & 2 & 1 & 1 & 1 & 1 & 1 & 1 \\
\hline 1 & 1 & 1 & 1 & 2 & 1 & 1 & 2 & 1 & 2 & 1 & 1 & 1 & 1 & 1 & 1 \\
\hline 1 & 1 & 1 & 1 & 1 & 1 & 1 & 1 & 1 & 1 & 1 & 1 & 1 & 1 & 1 & 2 \\
\hline 1 & 1 & 1 & 1 & 1 & 1 & 1 & 1 & 1 & 1 & 1 & 1 & 1 & 1 & 1 & 2 \\
\hline 1 & 1 & 1 & 1 & 1 & 1 & 1 & 1 & 1 & 1 & 1 & 1 & 1 & 1 & 1 & 2 \\
\hline 1 & 1 & 1 & 1 & 1 & 1 & 1 & 1 & 1 & 1 & 1 & 1 & 1 & 1 & 1 & 1 \\
\hline 1 & 1 & 1 & 1 & 1 & 1 & 1 & 1 & 1 & 1 & 1 & 1 & 1 & 1 & 1 & 2 \\
\hline 1 & 1 & 1 & 1 & 1 & 1 & 1 & 1 & 1 & 1 & 1 & 1 & 1 & 1 & 1 & 1 \\
\hline 1 & 1 & 1 & 1 & 1 & 1 & 1 & 1 & 1 & 1 & 1 & 1 & 1 & 1 & 1 & 1 \\
\hline
\end{tabular}

\section{Appendix II: SPSS Output}

Descriptive Statistics (Mean)
\begin{tabular}{|c|l|c|c|}
\hline S/N & Item Statement & N & Mean \\
\hline 1 & One of the responsibilities of internal audit staff is to prevent fraud at local government level & 78 & 3.59 \\
\hline 2 & Internal audit technique is a tool internal audit staff adopt in preventing fraud in the local government & 78 & 3.81 \\
\hline 3 & The management of the local government put all necessary measures in place, to prevent frauds & 78 & 2.89 \\
\hline 4 & The internal audit techniques adopted by the Internal audit unit at local government level are effective to prevent and detect fraud. & 78 & 3.56 \\
\hline 5 & IAU has been applying interview and analytic audit technique to prevent unauthorized disposal of local government assets & 78 & 3.65 \\
\hline 6 & IAU has been applying interview and analytic audit technique to prevent over-valuation of contracts and supplies & 78 & 3.62 \\
\hline 7 & IAU has been applying interview and analytic audit technique to prevent Improper related party transaction & 78 & 3.26 \\
\hline 8 & IAU has been applying interview and analytic audit technique to prevent Fictitious contracts and supplies & 78 & 3.81 \\
\hline 9 & IAU has been applying interview and analytic audit technique to prevent Diversion of funds/assets and unauthorized payment to third parties & 78 & 3.10 \\
\hline 10 & IAU has been applying interview and analytic audit technique to prevent Misappropriation of funds/assets. & 78 & 4.01 \\
\hline 11 & IAU has been applying interview and analytic audit technique to prevent Falsification of financial records & 78 & 2.86 \\
\hline 12 & IAU has been applying interview and analytic audit technique to prevent Submission of claims for services/goods not supplied & 78 & 3.85 \\
\hline 13 & Applying traditional system of auditing in the local government can prevent the above stated instances of frauds & 78 & 1.85 \\
\hline
\end{tabular}

Pearson Product Moment Product (r)

\begin{tabular}{|c|c|c|c|c|}
\hline \multirow{2}{*}{\multicolumn{2}{|c|}{$\begin{array}{l}\text { Interview and Analytic Technique } \\
\text { Traditional Technique }\end{array}$}} & 3.5000 & & 78 \\
\hline & & 1.8462 & & 78 \\
\hline \multicolumn{5}{|c|}{ Correlations } \\
\hline & & \multicolumn{2}{|c|}{ Interview and Analytic Technique } & Traditional Technique \\
\hline \multirow{3}{*}{ Interview and Analytic Technique } & Pearson Correlation & \multicolumn{2}{|c|}{1} & $.734^{+*}$ \\
\hline & Sig. (2-tailed) & & & .000 \\
\hline & $\mathrm{N}$ & \multicolumn{2}{|c|}{78} & 78 \\
\hline \multirow{3}{*}{ Interview and Analytic Technique } & Pearson Correlation & \multicolumn{2}{|c|}{$.734^{* *}$} & 1 \\
\hline & Sig. (2-tailed) & \multicolumn{2}{|c|}{.000} & \\
\hline & $\mathrm{N}$ & \multicolumn{2}{|c|}{78} & 78 \\
\hline
\end{tabular}

Chi-square Output

Case Processing Summary

\begin{tabular}{|l|c|c|c|c|c|c|}
\hline \multirow{2}{*}{} & \multicolumn{9}{c|}{ Cases } \\
\cline { 2 - 9 } & \multicolumn{2}{|c|}{ Valid } & \multicolumn{3}{c|}{ Missing } & \multicolumn{2}{c|}{ Total } \\
\cline { 2 - 9 } & $\mathrm{N}$ & Percent & $\mathrm{N}$ & Percent & $\mathrm{N}$ & Percent \\
\hline audit staff * analytic and interview technique & 78 & $49.7 \%$ & 79 & $50.3 \%$ & 157 & $100.0 \%$ \\
\hline
\end{tabular}

\begin{tabular}{|c|c|c|c|c|c|c|c|}
\hline \multicolumn{8}{|l|}{ Count } \\
\hline & & \multicolumn{5}{|c|}{ analytic and interview technique } & \multirow{2}{*}{ Total } \\
\hline & & strongly disagree & disagree & Neutral & agree & strongly agree & \\
\hline audit staff & Junior staff & 5 & 2 & 9 & 19 & 20 & 55 \\
\hline
\end{tabular}




\begin{tabular}{|c|c|c|c|c|c|}
\hline \multicolumn{1}{|c|}{ Senior staff } & 4 & 6 & 8 & 2 \\
\hline Total & 9 & & 8 & 17 & 21 \\
\hline \multicolumn{3}{|c|}{ Chi-Square Tests } \\
\hline & Value & Df & Asymp. Sig. (2-sided) \\
\hline Pearson Chi-Square & $18.479 \mathrm{a}$ & 4 & .001 \\
Likelihood Ratio & 18.716 & 4 & .001 \\
Linear-by-Linear Association & 11.471 & 1 & .001 \\
N of Valid Cases & 78 & & \\
\hline
\end{tabular}

a. 2 cells (20.0\%) have expected count less than 5 . The minimum expected count is 2.36 .

\begin{tabular}{|c|c|c|c|c|c|c|}
\hline \multicolumn{7}{|c|}{ Case Processing Summary } \\
\cline { 2 - 7 } & \multicolumn{2}{|c|}{ Cases } \\
\cline { 2 - 7 } & $\mathrm{N}$ & Palid & Missing & \multicolumn{2}{|c|}{ Total } \\
\hline Traditional Technique & 78 & $49.7 \%$ & 79 & $50.3 \%$ & 157 & $100.0 \%$ \\
\hline
\end{tabular}

category of staff in internal audit unit * Applying traditional system of auditing in the local government can prevent the above stated instances of frauds Cross tabulation

\begin{tabular}{|c|c|c|c|c|c|c|c|}
\hline \multirow{2}{*}{\multicolumn{8}{|c|}{ Count }} \\
\hline & & & & & & & \\
\hline & & \multicolumn{5}{|c|}{$\begin{array}{l}\text { Applying traditional system of auditing in the local government can } \\
\text { prevent the above stated instances of frauds }\end{array}$} & \multirow{2}{*}{ Total } \\
\hline & & strongly disagree & Disagree & Neutral & Agree & $\begin{array}{l}\text { strongly } \\
\text { agree }\end{array}$ & \\
\hline \multirow{3}{*}{$\begin{array}{l}\text { category of staff in } \\
\text { internal audit unit }\end{array}$} & Junior staff & 34 & 18 & 1 & 2 & 0 & 55 \\
\hline & Senior staff & 4 & 8 & 4 & 4 & 3 & 23 \\
\hline & Total & 38 & 26 & 5 & 6 & 3 & 78 \\
\hline
\end{tabular}

\begin{tabular}{l|c|c|c|}
\hline & Value & Df & Asymp. Sig. (2-sided) \\
\hline Pearson Chi-Square & $23.890^{\mathrm{a}}$ & 4 & .000 \\
Likelihood Ratio & 24.295 & 4 & .000 \\
Linear-by-Linear & 21.733 & 1 & .000 \\
Association & 78 & & \\
N of Valid Cases & & & \\
\hline
\end{tabular}

a. 6 cells $(60.0 \%)$ have expected count less than 5 . The minimum expected count is .88 .

Appendix IV

\begin{tabular}{|c|c|c|c|c|}
\hline \multirow{2}{*}{ S/NO } & \multirow{2}{*}{ Name of the local government } & \multirow{2}{*}{ No. of internal audit staff } & \multicolumn{2}{|c|}{ Category of staff } \\
\hline & & & Senior & Junior \\
\hline 1 & Gamawa & 7 & 5 & 2 \\
\hline 2 & Giade & 6 & 4 & 2 \\
\hline 3 & Itas Gadau & 6 & 4 & 2 \\
\hline 4 & Jama'are & 7 & 4 & 3 \\
\hline 5 & Katagum & 7 & 5 & 2 \\
\hline 6 & Shira-yana & 6 & 4 & 2 \\
\hline 7 & Zaki & 6 & 3 & 3 \\
\hline 8 & Bauchi & 9 & 5 & 4 \\
\hline 9 & Dambam & 7 & 5 & 2 \\
\hline 10 & Tafawa Balewa & 8 & 5 & 3 \\
\hline 11 & Bogoro & 7 & 4 & 3 \\
\hline 12 & Kirfi & 7 & 5 & 2 \\
\hline 13 & Ningi & 8 & 6 & 2 \\
\hline & Total & 91 & 59 & 32 \\
\hline
\end{tabular}

Source: Ministry for local government and chieftaincy affairs, staff disposition records, 2014 